Економічні науки: збірник наукових праџь Луцького національного технічного університету. - Серія "Регіональна економіка". - Випуск 15 (59). - Редкол.: відп. ред. д.е.н., професор Л.Л. Ковальська. - Луцьк: ІВВ Луцького НТУ, 2018. - 292 с.

УДК 339.188

Кулик Ю.М., к.е.н., асистент

Луцький національний технічний університет

\title{
ПРОБЛЕМИ ТА ПЕРСПЕКТИВИ РОЗВИТКУ ЛОГІСТИКИ РЕГІОНІВ УКРАЇНИ
}

Охарактеризовано особливості розвитку логістики в Україні та іiі регіонах. На основі значення показника логістичної ефективності в розрізі ключових параметрів визначено основні проблеми за кожним 3 них. Запропоновано напрямки, завдання та засоби досягнення стабільної логістики в Україні та іiі регіонах.

Ключові слова: логістика, інфраструктура, транспортування, технології, ефективність.

Kulyk I.M.

\section{PROBLEMS AND PROSPECTS OF LOGISTICS DEVELOPMENT IN UKRAINIAN REGIONS}

The growth of logistics role in the economy is due to several reasons. First, Ukraine, having an advantageous geographical location at the intersection of main roads from Europe and Asia, from Scandinavian countries to the Mediterranean, creates opportunities for the development of transit. Second, Ukraine has a powerful material and technical base for the development of the industrial complex, so it requires an expansion of new management methods using a logistic approach.

Third, the dynamic improvement of national and economic al bonds, which requires an increase in innovational, industrial, investment potential of the country to optimize costs. The main indicator which characterizes the efficiency of logistics is the international indicator of logistics efficiency - Logistics Perfomance Index, which is calculated every two years for such criteria: customs procedures, infrastructure, organization of deliveries, logistics competence, international transportation of goods, timeliness of delivery. Changing structure of goods turnover, reducing the volume of freight, increasing value cargo transportation on the main types of transport, outdated fixed assets, high corruption level in all spheres, insufficient investment attractiveness are the main inhibitors that hamper the development of logistics in the country. Studying the features and problems of logistics in Ukraine, we will form the core of the tasks for implementation of the stable logistics in Ukraine. The main objective is to provide a favorable microclimate for the growth of logistics capacity of the country, infrastructure development and implementation of the growth of performance indicators of logistics activity. To achieve the goal, we will define the main directions of logistics 
Економічні науки: збірник наукових праџь Луцького національного технічного університету. - Серія "Регіональна економіка". - Випуск 15 (59). - Редкол.: відп. ред. д.е.н., професор Л.Л. Ковальська. - Луцьк: ІВВ Луиького НТУ, 2018. - 292 с.

activity and means of their achievement. The advantage of an integrated approach is the versatility and flexibility that allows comprehensively grasp logistics problems and to consider alternatives managerial decisions from different angles.

Key words: logistics, infrastructure, transportation, technology, efficiency.

Кулык Ю.М.

\section{ПРОБЛЕМЫ И ПЕРСПЕКТИВЫ РАЗВИТИЯ ЛОГИСТИКИ РЕГИОНОВ УКРАИНЫ}

Охарактеризованы особенности развития логистики в Украине и ее регионах. На основе значения показателя логистической эффективности в разрезе ключевых параметров определены основные проблемы по каждому из них. Предложены направления, задачи и средства достижения стабильной логистики в Украине и ее регионах.

Ключевые слова: логистика, инфраструктура, транспортировки, технологии, эффективность.

Постановка проблеми у загальному вигляді і її зв'язок 3 важливими науковими та практичними завданнями. Ринкові відносини вимагають імплементації сучасних форм та методів управління підприємствами, що потребують якісного менеджменту. Логістика $є$ тим інструментом, що здатен забезпечити конкурентоспроможність регіонів, розвинути їхню інфраструктуру, реалізувати потенціал країни та надати безліч інших преваг. Разом з тим варто відмітити, що розвиток вітчизняної логістики та ринку логістичних послуг перебуває на стадії стабілізації. Світові тенденції, що їх використовують країни-лідери (Німеччина, Швеція, Бельгія, Австрія, Японія) стимулюють до пошуку нових технологій, форм та засобів задоволення потреб споживачів, отримання прибутку та зниження витрат.

Аналіз останніх досліджень, у яких започатковано вирішення проблеми. Особливості розвитку сучасної логістики та ринку логістичних послуг розкрито у працях Л.М. Шульгіної та В.В. Хажанець [1]. Ключові проблеми розвитку сучасної логістики в Україні та іiі регіонах висвітлює у своїх роботах М.О. Устенко та В.С. Івашкевич [2], О.С. Шандрівська та Л.Ю. Шевців [3]. 3'ясовує причини недостатньої розвинутості 
Економічні науки: збірник наукових праиь Луиького національного технічного університету. - Серія "Регіональна економіка". - Випуск 15 (59). - Редкол.: відп. ред. д.е.н., професор Л.Л. Ковальська. - Луцьк: ІВВ Луичького НТУ, 2018. - 292 с.

логістичних послуг в Україні у своїх напрацюваннях Ю.С. Петруня та Т.О. Пасічник [4].

Цілі статті. Мета статті полягає у дослідженні проблем та перспектив розвитку логістики в Україні та їі регіонах.

Виклад основного матеріалу дослідження 3 повним обгрунтуванням отриманих наукових результатів. Логістика $\epsilon$ фундаментальною сферою економіки країни, що прагне розвиватись та мати високі показники економічного розвитку. Зростання ролі логістики в економіці зумовлено кількома причинами. По-перше, Україна, маючи вигідне географічне розташування на перетині магістральних шляхів з Свропи та Азії та від скандинавських країн до Середземномор'я володіє можливостями для розвитку транзиту. По-друге, Україна має потужну матеріально-технічну базу для розвитку промислового комплексу, тим самим вимагаючи впровадження нових методів управління з використанням логістичного підходу. По-третє, розширення національних і економічних зв'язків, що вимагає нарощення інноваційного, виробничого, інвестиційного потенціалу країни для оптимізації витрат.

Так, за словами Прем’єр Міністра України, логістичний потенціал країни $є$ значним, однак він потребує розвитку та підтримки. Основна увага повинна бути зосереджена на підвищенні якості вітчизняної транспортної мережі (особливо контейнерні перевезення шляхом побудови портів), адже це сприятиме залученню іноземних інвестицій, впровадженню новітніх логістичних технологій та створенню нових робочих місць, виконуючи інвестиційну, інноваційну, суспільну та виробничу функції [5].

Важливим завданням в нарощенні логістичного потенціалу України та ії регіонів є розробка комплексу заходів, які слід імплементувати в кожному 3 регіонів України. Логістичний менеджмент включає функції планування, організації, аналізу та контролю матеріального та супутнього йому потоків. Лише завдяки синергічному ефекту від ефективної роботи логістики кожного регіону можливо усунути 
Економічні науки: збірник наукових праиь Луиького національного технічного університету. - Серія "Регіональна економіка". - Випуск 15 (59). - Редкол.: відп. ред. д.е.н., професор Л.Л. Ковальська. - Луцьк: ІВВ Луиького НТУ, 2018. - 292 с.

«вузькі місця» в управлінні та забезпечити нарощення логістичного потенціалу країни.

Основним показником, що характеризує ефективність логістики є міжнародний показник логістичної ефективності Logistics Perfomance Index, який розраховується кожних два роки за критеріями: митні процедури, інфраструктура, легкість організації поставок, логістична компетентність, міжнародне транспортування вантажів, своєчасність доставки.

За даними Світового банку, у 2018 році Україна посіла третє місце серед країн пострадянського простору (після Литви та Естонії) за індексом логістичної ефективності (LPI). У порівнянні з попередніми роками позиції України у 2018 році $є$ достатньо високими, зважаючи на ті «внутрішні» проблеми, 3 якими стикнулась економіка країни. Так, у 2010 році Україна займала 102 місце, а вже у 2018 році показник піднявся аж на 36 пунктів і займає 66 місце серед 160 країн світу [6].

Однак не дивлячись на це, існує низка проблем, 3 якими стикаються «гравці» на ринку логістики та логістичних послуг i які змушують функціонувати в умовах невизначеності та ризику [7-8].

Зміна структури товарообороту, зменшення обсягу вантажоперевезень, підвищення вартості вантажоперевезень на основних видах транспорту, застарілість основних засобів, висока корумпованість у всіх сферах, низька інвестиційна привабливість - основні інгіблітори, що гальмують розвиток логістики в країні. Для вирішення цих та решти проблем необхідним і важливим завданням є ідентифікація причин їх виникнення для ретельного аналізу та розробки комплексу управлінських рішень, що будуть націлені на усунення їх негативного впливу (рис. 1).

Виходячи 3 даних, що представлені на рис. 1 розглянемо детальніше значення показника логістичної ефективності (LPI) за кожним з параметрів 3 метою виявлення «вузьких місць» та «сильних сторін».

Митні процедури. Значна кількість часу та інших ресурсів відводиться на оформлення документів, які потрібні для 
Економічні науки: збірник наукових праџь Луцького національного технічного університету. - Серія "Регіональна економіка". - Випуск 15 (59). - Редкол.: відп. ред. д.е.н., професор Л.Л. Ковальська. - Луцьк: ІВВ Луиького НТУ, 2018. - 292 с.

замитнення/розмитнення товарів, надання відповідних дозволів на перетинання кордонів. Пов'язано це 3 тим, що не на всіх міжнародних пунктах пропуску (автомобільного та залізничного транспорту) впроваджено електронне декларування, що значно спрощує та прискорює процедуру оформлення документів. Акцент уваги має бути зосереджений на автоматизації процесів, що нададуть можливість спростити митні процедури, адже це дозволить збільшити обсяг товарообороту.

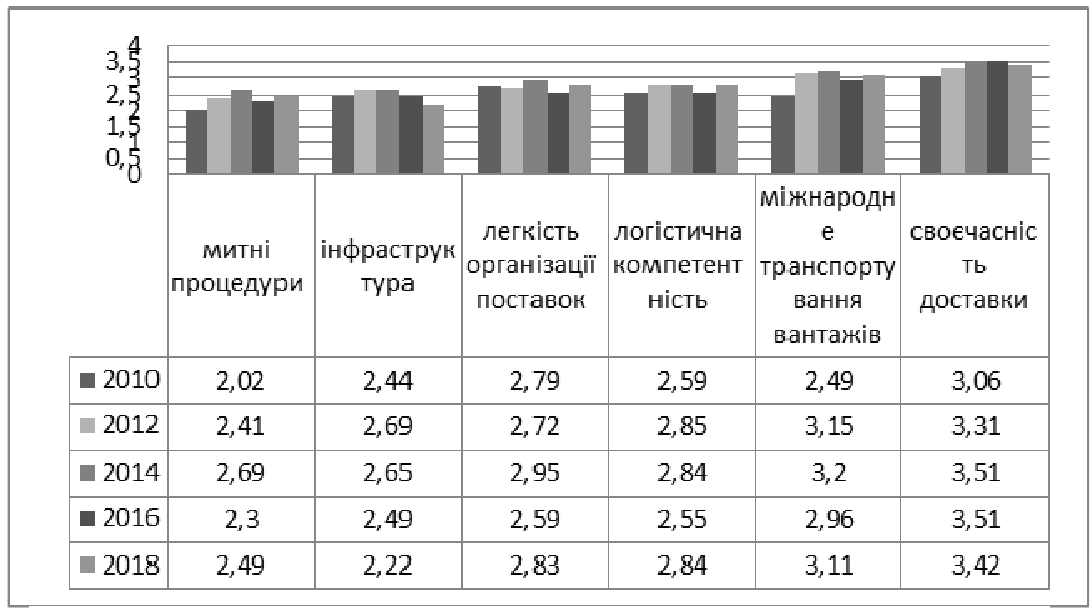

Рис. 1. Індекс логістичної ефективності України за 2010-2018 рр.

Інфраструктура. Спектр логістики та транспорту i логістики в Україні перебуває на етапі формування, порівняно 3 іншими європейськими країнами. Причиною тому $\epsilon$ нестабільний інвестиційний клімат для вливання інвестицій та постійні зміни в законодавстві. Для створення ефективної та дієвої логістичної інфраструктури необхідно застосовувати спеціальну методологію, реінжиніринг логістичних процесів, а не часткову їх зміну, що в результаті не принесе очікуваного результату.

Легкість організації поставок. Такі концепції логістики як Kanban, Just in time, MRP не є чимось новим для ринку 
Економічні науки: збірник наукових праџь Луцького національного технічного університету. - Серія "Регіональна економіка". - Випуск 15 (59). - Редкол.: відп. ред. д.е.н., професор Л.Л. Ковальська. - Луцьк: ІВВ Луцького НТУ, 2018. - 292 с.

логістичних послуг. Адже кожен 3 «гравців» на ринку логістичних послуг зацікавлений в тому, щоб своєчасно та в повному обсязі отримувати/надавати товар (послугу), утримуючи свої ринкові позиції. Висока конкуренція, впровадження сучасних технологій, інформаційна доступність вимагає активного апгрейду логістичних продуктів 3 метою скорочення логістичного циклу.

Логістична компетентність. Як у 2000-х роках не було чіткого розуміння поняття «менеджмент» та спеціальності «менеджер» і відповідно з'являлись такі робочі одиниці у підприємництві як: менеджери торгових залів (завгоспи), менеджери 3 персоналу (фахівець 3 кадрів), менеджери 3 продажу (брокери, дилери, комівояжери), так і пізніше, після 2010-го року активного поширення набрали поняття «логістика» i «логіст», які асоціювались лише 3 транспортуванням та складуванням, неправомірно обмежуючи коло функцій, що виконує логістика. Нині, однією 3 причин слабкого розвитку логістики (порівняно 3 провідними європейськими країнами) $є$ те, що готують фахівців, які $є$ лише теоретиками і зовсім не ознайомлені з тим, що зустрічається на підприємстві, вимагаючи тим самим проведення на підприємстві відповідних тренінгів, коучів для перекваліфікації або підвищення кваліфікації кадрів 3 логістики.

Міжнародне транспортування вантажів. На сьогодні існує загальна збірка правил міжнародного перевезення INCOTERMS 2010, де чітко розписано, хто відповідає за вантаж (продавець, покупець, замовник, виконавець, посередник тощо) i до якого моменту, хто платить за транспортування і хто несе ризики. Однак у зв'язку з постійним ростом цін на паливо, щорічною проблемою отримання дозволів на перевезення (осінньо-зимовий період), необхідним і важливим завданням $є$ забезпечення оперативності перевезення, забезпечення гнучкості маршрутів перевезень, контролю на всіх етапах перевезень.

Своєчасність доставки. Ефективність організації процесу перевезень характеризується такими критеріями як: своєчасність 
Економічні науки: збірник наукових праць Луиького національного технічного університету. - Серія "Регіональна економіка". - Випуск 15 (59). - Редкол.: відп. ред. д.е.н., професор Л.Л. Ковальська. - Луцьк: ІВВ Луцького НТУ, 2018. - 292 с.

доставки, тривалість доставки, витрати у процесі транспортування, продуктивність, прибуток. Для забезпечення своєчасності доставки необхідно узгодити роботу кожної із ланок логістичної системи: виробничої, транспортної, обслуговуючої та забезпечувати страхування по максимуму всіх можливих ризиків, які можуть виникати.

Дослідивши особливості та проблеми логістики в Україні, сформуємо коло основних завдань для забезпечення стабільної логістики в Україні та їі регіонах (рис. 2).

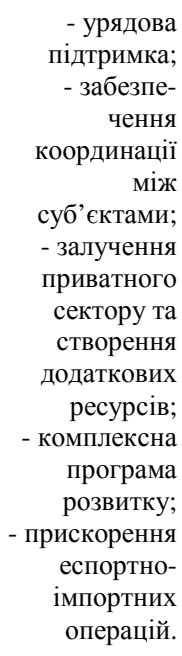

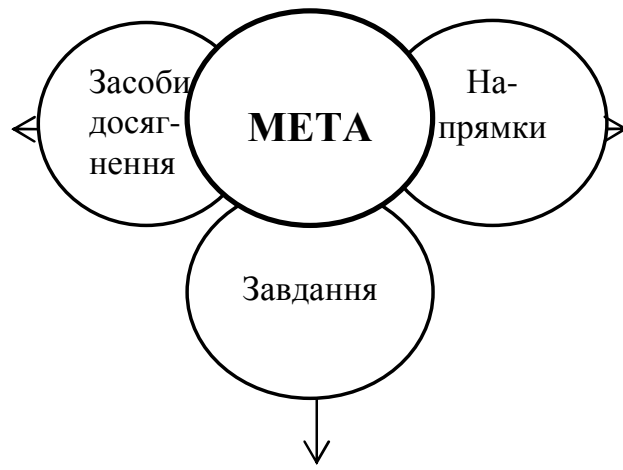

- реалізація логістичного потенціалу;

- посилення мультимодальності та взаємосполучованості між різними видами транспорту;

- розширення логістичної інфраструктури;

- підвищення кваліфікації персоналу з логістики;

- сприяння торгівлі. впрова-

дження

конкурентної

транспортної

системи;

- інноваційний розвиток транспортного сектору;

- $\quad$ впрова-

дження

стратегічних інноваційних проектів;

- забезпечення енергоефективного транспорту; - забезпечення регіональної інтеграції.

\section{Рис. 2. Мета, напрямки, завдання та засоби досягнення} стабільної логістики в Україні та їі регіонах 
Економічні науки: збірник наукових праџь Луцького національного технічного університету. - Серія "Регіональна економіка". - Випуск 15 (59). - Редкол.: відп. ред. д.е.н., професор Л.Л. Ковальська. - Луцьк: ІВВ Луцького НТУ, 2018. - 292 с.

Основною метою $є$ забезпечення сприятливого мікроклімату для нарощення логістичного потенціалу країни, розвитку інфраструктури та забезпечення зростання показників ефективності логістичної діяльності. Для досягнення мети визначимо основні напрямки діяльності та засоби їх досягнення. Перевагою комплексного підходу $\epsilon$ багатоваріантність та гнучкість, що дозволяє всебічно підійти до проблем логістики та 3 різних позицій розглянути альтернативні варіанти управлінських рішень.

Висновки. Одним 3 основних завдань уряду країни $\epsilon$ розбудова інфраструктури ринку логістики України та іiі регіонів шляхом реалізації логістичних проектів, побудови транспортних коридорів з метою зміцнення економіки країни.

1. Шульгіна Л.М., Хажанець В.В. Сучасні тенденції розвитку транспортної логістики в Україні. Молодий вчений. 2018. №4 (56). С. 172-174.

2. Устенко М.О., Івашкевич В.С. Перспективи розвитку транспортнологістичних систем України. Вісник економіки транспорту і промисловості. 2017. №59. С. 84-90.

3. Шандарівська О.Є., Шевців Л.Ю. Комплексний аналіз ринку логістичних послуг в Україні. Актуальні проблеми економіки. 2016. №7 (181). C. $163-173$.

4. Петруня Ю.С., Пасічник Т.О. Вплив новітніх технологій на логістику та управління ланцюгами поставок. Маркетинг і менеджмент інновацій. 2018. №1. С. 130-139.

5. Україна потрапила до ТОП пострадянських країн 3 найкращою логістикою. Сьогодні.uа - Липень, 30, 2018. URL:

https://ukr.segodnya.ua/economics/transport/ukraina-popala-v-toppostsovetskih-stran-s-luchshe-logistikoy-1158634.html

6. Україна піднялась у рейтингу логістики СБ. КорреспонденТ.net Серпень, 5, 2018. URL:

https://ua.korrespondent.net/world/worldabus/3997484-ukraina-pidnialasiav-reitynhu-lohistyky-sb

7. В Україні індекс ефективності логістики на $40 \%$ нижче за показник країн-лідерів - АгроІнсайдер. Травень, 5, 2018. URL:

https://agroinsider.com.ua/2018/05/25/v-ukra\%D1\%97ni-indeksefektivnosti-logistiki-na-40-nizhche-za-pokaznik-kra\%D1\%97n-lideriv/

8. Було б що возити: огляд ринку логістики України. Pro Consulting. Травень, 21, 2018. URL: https://pro-consulting.ua/ua/pressroom/bylo-by-chtovozit-obzor-rynka-logistiki-ukrainy 